\title{
JEDEN NARÓD - JEDEN JĘZYK? \\ RUCH ENGLISH-ONLY W KONTEKŚCIE WCZEŚNIEJSZYCH PRÓB UREGULOWANIA STATUSU JEZZYKA ANGIELSKIEGO W STANACH ZJEDNOCZONYCH
}

We must have but one flag. We must also have but one
language. That must be the language of the Declaration
of Independence, of Washington's Farewell address,
of Lincoln's Gettysburg Speech and second inaugural.

Theodore Roosevelt'

America is great not because we speak one language or the other, but because we are unified by the fundamental principles [that] bind our people together (...). To say that we make our country stronger because we make it "U.S. English" is like saying that we would make it stronger by making it "U.S. white".

Baltasar Corrada ${ }^{2}$

\section{WPROWADZENIE}

Z

najomość angielskiego postrzegana jest jako niezbywalny element tożsamości amerykańskiej, choć nie od samego początku istnienia Stanów Zjednoczonych język ten zajmował tak ważne miejsce w panteonie symboli narodowych. Stało się to dopiero na początku XX w., wraz z prowadzoną na szeroką skalę kampanią amerykanizacji imigrantów. Ponieważ język macierzysty grup imigranckich odzwierciedla ich korzenie etniczne, tradycję oraz sposób postrzegania świata, zmiana języka kraju macierzystego na język angielski

Dr Anna KAGANIEC-KAMIEŃSKA jest adiunktem w Instytucie Amerykanistyki i Studiów Polonijnych Uniwersytetu Jagiellońskiego w Krakowie. a.kaganiec-kamienska@uj.edu.pl

Theodore Roosevelt, „The Children of the Crucible” (1917), cyt. w.: James Crawford (ed.), Language Loyalties, The University of Chicago Press, Chicago 1992, s. 85.

2 Baltasar Corrada - komisarz rezydent Portoryko (Resident Commisioner of Puerto Rico) w Izbie Reprezentantów USA w latach 1977-1985. Cytat pochodzi z The English Language Amendment: Hearing on S.J. Res. 167 (1984), cyt. w: James Crawford (ed.), Language Loyalties, op. cit., s. 120-121. 
(language transition) jest jednym z istotnych wskaźników świadczących o zachodzącym procesie asymilacji imigrantów i ich potomków³.

Status angielskiego nie jest jednak, ku zaskoczeniu również wielu Amerykanów, prawnie uregulowany. Ani w Konstytucji, ani w innych regulacjach federalnych nie znajdziemy zapisu nadającego mu status języka oficjalnego czy urzędowego. A jednak na przestrzeni czasu dołożono starań, by zapewnić angielskiemu dominację na terenach przyłączonych w wyniku ekspansji terytorialnej ${ }^{4}$, próbowano także wymusić asymilację językową na imigrantach. Skoro jednak angielski nie jest językiem oficjalnym USA, a sam kraj podkreśla swoje imigranckie korzenie, można postawić pytanie o zasadność tych działań.

Restrykcyjna polityka względem języków obcych w USA w dużym stopniu zależała od ogólnie panującej sytuacji społeczno-politycznej w kraju oraz natężenia fal imigracyjnych. Pierwsze głosy niezadowolenia z dużego napływu Niemców słychać było w niektórych stanach już w okresie kolonialnym. Szczególny opór wzbudziła zaś wielka imigracja z Europy w latach 1880-1920. Szeroko zakrojoną kampanię amerykanizacji z tego okresu oraz wprowadzane restrykcje językowe argumentowano m.in. pragnieniem zachowania "amerykańskości" USA, potrzebą asymilacji imigrantów, a w wypadku wrogości wobec Niemców w czasie I i II wojny światowej oraz Japończyków po ataku na Pearl Harbor - potrzebą zapewnienia bezpieczeństwa wewnętrznego kraju ${ }^{5}$.

W ostatnich latach $w$ związku ze zmieniającym się składem rasowo-etnicznym populacji kraju na skutek szybkiego wzrostu liczebnego zwłaszcza grupy latynoskiej, silnie zarysowały się niepokoje tej części społeczeństwa, która obawia się zmian kulturowych. Towarzysząca imigracji debata na temat reformy polityki imigracyjnej oraz wprowadzane regulacje prawne i środki mające na celu uszczelnienie granicy w konsekwencji potęgują obawy. Ich odzwierciedleniem jest zapoczątkowany w latach 80. ruch English-Only, działający na rzecz zagwarantowania prawnego statusu języka angielskiego. I chociaż działania mające na celu ograniczanie użycia innych języków podejmowane były, jak wspomniano, już wcześniej (lokalnie), jednak to właśnie lata 80. dały początek szeroko zakrojonym kampaniom na rzecz uznania angielskiego za język oficjalny kraju. Jak dotąd zwolennikom tej regulacji nie udało się wprowadzić zapisu o oficjalnym języku na poziomie federalnym, jednak angielski uzyskał taki status w wielu stanach (Official English).

Artykuł ma na celu przedstawienie działalności ruchu English-Only w kontekście wcześniejszych prób ograniczania użycia innych języków, z uwzględnieniem wybranych istniejących regulacji prawnych (na poziomie federalnym, stanowym i lokalnym).

\section{OGRANICZANIE UŻYCIA JĘZYKÓW MACIERZYSTYCH IMIGRANTÓW DO LAT OSIEMDZIESIĄTYCH XX WIEKU}

Na terenie dzisiejszych Stanów Zjednoczonych od samego początku wspótistniały różne grupy narodowe, a zatem i językowe. Wśród pierwszych przybyszów, poza Anglikami,

3 Ilustruje to na przykład "Survey Brief - Assimilation and language", Pew Hispanic Center and The Kaiser Family Foundation, Washington, D.C., March 2004, http://pewhispanic.org/files/reports/15.10.pdf (16.02.2010).

4 Zob.: Anna Kaganiec-Kamieńska, „Amerykańska polityka językowa wobec terenów przyłączanych w wyniku ekspansji terytorialnej” - artykuł złożony do druku (Politeja, Pismo Wydziału Studiów Międzynarodowych i Politycznych UJ).

5 Por.: Thomas Ricento, „A Brief History of Language Restrictionism in the United States”, 1996, http://www. usc.edu/dept/education/CMMR/PolicyPDF/OfficialEnglishRicento.pdf, s. 1 (12.01.2010). 
znajdowali się Hiszpanie, Francuzi, Holendrzy, Niemcy, a także Szwedzi i Finowie ${ }^{6}$. Ojcowie Założyciele mieli jednak praktyczne podejście do języków i nie umieścili zapisu o języku oficjalnym czy narodowym w Konstytucji Stanów Zjednoczonych?.

Grupy przybyszów w różnym stopniu asymilowały się językowo. Pośród tych, którym przychodzito to zdecydowanie najszybciej, znajdowali się Holendrzy oraz Szwedzi ${ }^{8}$. Tymi, którzy długo opierali się utracie języka i kultury, byli Niemcy - zwłaszcza jeśli mieszkali w dużych skupiskach, a ich społeczności odnotowywały ciągły napływ nowych imigrantów. Niemcy byli wówczas największą grupą nieanglojęzyczną i stanowili jedną trzecią ludności Pensylwanii. Z tego względu stali się jednym z pierwszych celów ataków.

Nie kto inny, jak Benjamin Franklin, który sam wcześniej bez powodzenia próbował wydawać niemieckojęzyczną gazetę, niejednokrotnie wyrażał obawy, że Niemcy nie chcą się asymilować, przez co doprowadzą do germanizacji kolonii. W 1753 r. w liście do Petera Collinsona, członka Parlamentu brytyjskiego, napisał m.in.: „Ci [Niemcy], którzy tutaj przybywają są ogólnie rzecz biorąc najbardziej ignorancką Głupią Odmianą z ich Narodu"9. Zarzucił im m.in., że nie uczą się angielskiego, a język niemiecki znajduje się w powszechnym użyciu - na znakach drogowych czy w gazetach. Wyraził opinię, że jeśli ich napływająca fala nie zwróci się ku innym koloniom, wkrótce liczba Niemców w Pensylwanii na tyle przekroczy liczbę Anglików, że nie uda się zachować języka angielskiego ${ }^{10}$. W Observations on the Increase of Mankind z 1755 r. nazwat ich nawet "Palatine boors", a więc „palatyńskimi prostakami”, jednak fragment ten został usunięty z kolejnych wydań. Jak sugeruje James Crawford, Ojciec Założyciel musiał bowiem poczuć się zawstydzony swoimi słowami ${ }^{11}$. Przypłacit je w 1764 r. przegraną w wyborach do zgromadzenia kolonii właśnie głosami Niemców. W późniejszym okresie zmienił jednak nastawienie względem tej grupy, a nawet miał popierać edukację wyższą po niemiecku².

Liczebność i pozycja grupy niemieckiej pod koniec XVIII w. była na tyle silna, że stała się źródłem legendy (tzw. Muhlenberg legend). Według niej, tylko jeden głos zdecydował o tym, że niemiecki nie został językiem narodowym USA. W rzeczywistości, jak podaje Carol L. Schmid, chodzi o petycje grupy Niemców z Wirginii, by niektóre prawa federalne ukazywały się zarówno po angielsku, jak i po niemiecku. W głosowaniu w Izbie Reprezentantów w 1795 r. propozycja ta została ostatecznie odrzucona - jednym głosem (42-41), należącym prawdopodobnie do Fredericka Augusta Muhlenberga (spikera Izby Reprezentantów) ${ }^{13}$.

Obecnie dialekt Pennsilfaanisch Deitsch, czyli Pennsylvania German, określany także jako Pennsylvania Dutch, używany jest przez około 300 tys. osób w USA - głównie w Pensylwanii, Ohio oraz Indianie - a także przez kilka tysięcy w Kanadzie (Ontario) ${ }^{14}$.

\section{$\cdots \cdot \cdots$}

6 Na temat składu populacji kolonii szerzej zob. np.: Roger Daniels, Coming to America. A History of Immigration and Ethnicity in American Life, Perennial, New York 2002, s. 30-52, 66-100; Diego Castellanos, The Best of Two Worlds: Bilingual-Bicultural Education in the US (1983), w: James Crawford (ed.), Language Loyalties, op. cit., s. 13-18.

7 Zob. np.: Anna Kaganiec-Kamieńska, „Amerykańska polityka językowa wobec terenów przyłączanych w wyniku ekspansji terytorialnej", op. cit.

8 Tu i dalej: Carol L. Schmid, The Politics of Language. Conflict, Identity, and Cultural Pluralism in Comparative Perspective, Oxford University Press, New York 2001, s. 21.

9 Ang. "Those [Germans] who come hither are generally that most ignorant Stupid Sort of their Nation (...)" Cyt. z listu do Petera Collinsona (1753), w: James Crawford (ed.), Language Loyalties, op. cit., s. 19.

10 Benjamin Franklin, fragment listu do Petera Collinsona (1753), w: James Crawford (ed.), Language Loyalties, op. cit., s. 19.

11 Za: Carol L. Schmid, op. cit., s. 15.

12 James Crawford, At War with Diversity. US Language Policy in an Age of Anxiety, Multilingual Matters Ltd., 2001, s. 12.

13 Carol L. Schmid, op. cit., s. 17. Szerzej zob. też: Dennis Baron, The English-Only Question, Yale University Press, New Heaven 1990, s. 88-90.

14 „Hiwwe wie Driwwe: A Pennsylvania German publication”, Amish America, 18 January 2009, http:// amishamerica.typepad.com/amish_america/amish_language/ (20.12.2009). 
Liczba osób powyżej 5. roku życia posługujących się nim w domu w 1990 r. została oszacowana przez U.S. Census na ponad 83,5 tys. osób ${ }^{15}$. Znaczącą większość jego użytkowników stanowią dziś członkowie społeczności amiszów oraz menonitów. W języku tym ukazują się kolumny w niektórych gazetach Ohio i Pensylwanii, można go też usłyszeć w radio. Język ten zbliżony jest do dialektu Phaelzisch, jakim w Niemczech posługują się mieszkańcy doliny Renu w okolicach Mannheim ${ }^{16}$.

Imigranci przybywający do USA do II połowy wieku XIX spotykali się raczej z przychylnością i życzliwością, stosunkowo rzadko, z wyjątkiem wspomnianych otwartych ataków na Pennsylvania Germans, padali ofiarą restrykcji. W USA funkcjonowały kościoły oraz szkoły przykościelne, w których mówiono w językach narodowych, np. niemieckim czy szwedzkim. Zaczęły też powstawać szkoły dwujęzyczne - zarówno prywatne, jak i państwowe ${ }^{17}$. W 1839 r. Ohio jako pierwsze oficjalnie zezwoliło na nauczanie dwujęzyczne (niemiecko-angielskie), które miało się odbywać na prośbę rodziców ${ }^{18}$. W czasie I wojny światowej Niemcy doświadczyli jednak silnych represji w USA - ich język zniknął ze szkół, niemieckojęzyczne gazety oraz instytucje kulturalne znalazły się pod ostrzałem.

Początkowe ogólnie życzliwe nastawienie wobec imigrantów uległo zmianie pod koniec lat 80. XIX w. Wtedy to $w$ stanach Wisconsin i Illinois pojawity się pierwsze regulacje ustanawiające angielski wyłącznym językiem nauczania w szkołach publicznych oraz parafialnych ${ }^{19}$. Przełom XIX i XX w. był bowiem w historii Stanów Zjednoczonych okresem masowej imigracji z Europy. Fala ta była tak znacząca, że na początku wieku XX niemal 90\% imigrantów pochodziło z Europy, a w 1910 r. prawie 15\% populacji kraju stanowili imigranci (foreign born) ${ }^{20}$. Nastąpiła jednocześnie zmiana w strukturze imigracji europejskiej. O ile pośród imigrantów przybyłych do lat 1880. dominowały osoby z Europy Północnej i Zachodniej (głównie z Niemiec, Irlandii oraz Anglii), o tyle na przełomie wieków dołączyli do nich również, a wkrótce przewyższyli ich liczebnie imigranci z Europy Południowej oraz Środkowo-Wschodniej (Włosi, Polacy, przybysze z Austro-Węgier oraz Rosji). W związku z dużym napływem imigrantów na przełomie wieków dały o sobie znać radykalne ruchy natywistyczne (np. Know-Nothings, u podstaw działalności których leżał duży napływ katolickich Irlandczyków i rzekome zagrożenie, jakie stanowili oni dla amerykańskiej kultury).

Od początku XX w. amerykanizacja miała już swoich zwolenników wśród szerszej rzeszy ludności, m.in. intelektualistów, pracowników społecznych, przedsiębiorców, ale także osób działających na polu edukacji21. Nie jest to dziwne, jeśli wziąć pod uwagę, że już od połowy XIX w. pojawiały się w USA teorie naukowe dowodzące niższości osób czarnoskórych oraz mniejszych zdolności intelektualnych imigrantów ${ }^{22}$. Badanie 10 przeprowadzone w 1912 r. przez Henry'ego Goddarda na określonej próbie osób miało dowodzić, że 83\% Żydów, 80\% Węgrów, 79\% Włochów oraz 87\% Rosjan niedawno przybyłych do

\section{$\cdots \cdots \cdots$}

15 „Detailed Language Spoken at Home and Ability to Speak English for Persons 5 Years and Over - 50 Languages with Greatest Number of Speakers: United States 1990", U.S. Census Bureau, http://www.census. gov/population/socdemo/language/table5.txt (20.12.2009).

16 Szerzej na temat tego języka zob. np.: "A Very Brief Introduction to the Pennsylvania German Language”, The Pennsylvania German Society, http://www.pgs.org/dialect.asp (20.12.2009); German Pennsylvanian Association, http://dpak.wordpress.com/english-version/ (20.12.2009).

17 Szerzej zob.: Carol L. Schmid, op. cit., s. 19-21.

18 James Crawford, At War with Diversity, op. cit., s. 20

19 Ibid.

20 Campbell J. Gibson, Emily Lennon, „Historical Census Statistics on the Foreign-born Population of the United States: 1850-1990", U.S. Census Bureau, February 1999, Tabele 2 i 12, http://www.census.gov/ population/www/documentation/twps0029/twps0029.html (20.12.2009).

21 Dennis Baron, op. cit., s. 133

22 Szerzej zob. np.: Jerzy Wiatr, Zagadnienia rasowe w socjologii amerykańskiej, PWN, Warszawa 1959, s. 17-60. Zob. też: Carol L. Schmid, op. cit., s. 37-41. 
USA okazało się „ułomnymi umystowo" (feeble-minded)23. Wyniki te, jak podaje Thomas Ricento, pomogły wprowadzić kwoty imigracyjne w 1924 r. (Johnson-Laird Immigration Act). Również Raport Komisji Dillinghama z 1911 r. sugerował nieprzystosowanie imigrantów do życia w USA ${ }^{24}$. Pojawiały się co prawda głosy w obronie nowych imigrantów i ich znaczenia dla kraju. Osobą, która wyrażała się o nich pochlebnie był Horace Kallen, jednak nawet on uważat, jak pisze Dennis Baron, że od imigrantów powinno się wymagać znajomości języka angielskiego ${ }^{25}$.

Największa kampania na rzecz amerykanizacji, z naciskiem na upowszechnianie języka angielskiego, miała miejsce w pierwszych dwóch dekadach XX w. ${ }^{26}$ Przyczyniła się do niej również obawa przed szerzeniem się rewolucyjnych nastrojów wśród imigranckich robotników. Do 1923 r. aż 34 stany wprowadziły nauczanie po angielsku - zarówno w szkołach publicznych, jak i prywatnych ${ }^{27}$. Jedynie w latach 1919-1921 około 20 stanów przyjęło statuty dotyczące amerykanizacjij ${ }^{28}$. Obowiązkowe zajęcia z angielskiego dla swoich pracowników wprowadzały też niektóre zakłady pracy, na przykład Ford Motor Company. Nauczanie języka wydaje się kluczowe w programach amerykanizacji, jednak nie istniała zgoda co do tego, czy nauka ta miała być obowiązkowa czy też dobrowolna.

Poszczególne stany wprowadzały również inne zapisy ograniczające użycie innych języków. Nowy Jork (oraz kilka innych stanów) wprowadził wymóg, by nauczyciele w szkołach publicznych byli obywatelami USA, zaś stan Oregon - obowiązek zamieszczania angielskich tłumaczeń tekstów publikowanych w prasie obcojęzycznej ${ }^{29}$. Jak zauważył Crawford: „w tym okresie po raz pierwszy ustanowiono ideologiczny związek pomiędzy mówieniem "dobrze po angielsku» a byciem "dobrym Amerykaninem»"30.

Język sam w sobie stał się $w$ tym czasie istotnym elementem polityki imigracyjnej i naturalizacyjnej Stanów Zjednoczonych. W 1906 r. wprowadzono wymóg podstawowej znajomości angielskiego, aby uzyskać obywatelstwo amerykańskie. Piśmienność przybyszów (w angielskim lub jakimkolwiek innym języku) stała się natomiast kryterium przyjęć imigrantów do USA w 1917 r., kiedy po raz pierwszy przeprowadzono Literacy Test ${ }^{31}$. Test ten funkcjonował jako główne narzędzie ograniczające imigrację do początku lat 20., kiedy wprowadzono kwoty imigracyjne ${ }^{32}$. Przyjęcie restrykcyjnego systemu kwotowego w prawie imigracyjnym (1921 i 1924 r.). było punktem kulminacyjnym kampanii amerykanizacji. Niemal całkowicie zahamowało to imigrację z Europy Południowej oraz Środkowo-Wschodniej. Późniejsze przepisy imigracyjne (Walter-McCarran Act z 1952 r. oraz Immigration Act z 1965 r.) doprowadziły do zasadniczej zmiany składu imigrantów. Obecnie, jak wynika z danych spisowych U.S. Census Bureau z 2000 r., wśród osób urodzonych poza USA (foreign-born) zdecydowanie dominują osoby z Ameryki Łacińskiej (ok. 52\%) - głównie z Meksyku, oraz Azji (ok. 26\%) - głównie z Chin i Filipin ${ }^{33}$.

23 Thomas Ricento, op. cit., s. 4

Szerzej zob.: Dennis Baron, op. cit., s. 134-135

Dennis Baron, op. cit., s. 135-136.

26 Szerzej zob.: Carol L. Schmid, op. cit., s. 34-37; John Higham, Strangers in the Land: Patterns of American Nativism, 1860-1925 (1988), w: James Crawford (ed.), Language Loyalties, op. cit., s. $72-84$.

27 Joseph Leibowicz, op. cit., s. 105.

28 Szerzej na temat legislacji w tym okresie zob.: Dennis Baron, op. cit., s. 141-150.

29 John Higham op. cit., s. 83

30 James Crawford, At War with Diversity, op. cit., s. 21

31 Joseph Leibowicz, op. cit., s. 106-107.

32 Szerzej na temat testu zob.: Roger Daniels, op. cit., s. 276-279.

33 Nolan Malone, Kaari F. Baluja, Joseph M. Costanzo, Cynthia J. Davis, „The Foreign-Born Population”, Census 2000 Brief, U.S. Census Bureau, December 2003, http://www.census.gov/prod/2003pubs/c2kbr-34.pdf (12.01.2010), s. 5 . 
Szczególnie duży napływ imigrantów z Ameryki Łacińskiej oraz fakt, że w połowie 2006 r. grupa Hispanic/Latinos stanowiła ponad 14,8\% (44,3 mln$)^{34}$ populacji kraju i szybko wzrasta liczebnie - przyczynia się do postrzegania ich jako niechętnie uczących się angielskiego. Dodatkowo, jak argumentują krytycy, po raz pierwszy w historii większość imigrantów posługuje się tylko jednym językiem - hiszpańskim. Stanowi to, ich zdaniem, zagrożenie dla przyszłości języka angielskiego w USA.

\section{RUCH ENGLISH ONLY}

Początków dążeń do ustanowienia angielskiego językiem oficjalnym Stanów Zjednoczonych należy doszukiwać się około roku 1980. W 1981 r. senator Samuel Ichiye Hayakawa, o japońskich korzeniach (sic!), zaproponował poprawkę do Konstytucji USA, która miała na celu ustanowienie angielskiego językiem oficjalnym ${ }^{35}$. Chociaż projekt ten nie został ostatecznie poddany pod głosowanie Kongresu, był jednak pierwszym, który wnosił o regulację statusu języka angielskiego, jeśli wyłączyć projekt z 1923 r. ustanowienia „amerykańskiego" językiem oficjalnym USA ${ }^{36}$. Propozycję taką wysunął wówczas Washington J. McCormick, republikanin z Montany, i była ona próbą "mentalnej emancypacji” (mental emancipation) oraz określenia amerykańskiej odmienności, również literackiej, względem Imperium Brytyjskiego. Ostatecznie nie doszło do głosowania nad nią w Kongresie, niemniej była to pierwsza propozycja ustanowienia jezzyka oficjalnego USA, jaka trafiła do Kongresu.

W 1983 r. Sayakawa założył wraz z Johnem Tantonem organizację U.S. English, lobbującą na rzecz uregulowania statusu angielskiego jako języka oficjalnego kraju. Był to rzeczywisty początek ruchu English Only, zrodzonego z przekonania o zagrożonej pozycji angielskiego.

Zwolennicy Official English uważają, że regulacja ta byłaby korzystna zarówno dla Amerykanów, jak i amerykańskiego rządu. Na oficjalnej stronie internetowej organizacji U.S. English przytaczane są m.in. następujące argumenty za uregulowaniem statusu angielskiego ${ }^{37}$. Po pierwsze, sprzyjałoby to jedności wszystkich Amerykanów. Wielość języków, jakimi posługują się mieszkańcy USA, powoduje bowiem konflikty rasowe i etniczne, a równocześnie daje poczucie imigrantom, że nie muszą uczyć się angielskiego, skoro rząd zapewnia im pomoc w innych językach (np. formularze w różnych instytucjach). Po drugie, Official English dałby imigrantom szansę pełnego uczestnictwa w społeczeństwie amerykańskim oraz możliwość realizacji „amerykańskiego snu”, gdyż brak znajomości angielskiego uniemożliwia awans zawodowy i społeczny. Po trzecie, Official English byłby korzystny dla rządu amerykańskiego, wyeliminowałby bowiem potrzebę zagwarantowania obywatelom pomocy w wielu językach. Pieniądze w ten sposób zaoszczędzone mogłyby zostać przeznaczone na nauczanie imigrantów języka angielskiego.

Ustanowienie angielskiego językiem oficjalnym nie oznacza, że użycie innych języków nie byłoby możliwe w sytuacjach wyjątkowych, na przykład w nagłych wypadkach,

34 „Minority Population Tops 100 Million”, US Census Bureau News, May 17, 2007, http://www.census.gov/ Press-Release/www/releases/archives/population/010048.html (12.01.2010).

35 Tekst propozycji: S. J. Res. 72 (Hayakawa) z 27 kwietnia 1981 r. dostępny na stronie http://www.languagepolicy.net/archives/ela97.htm (12.01.2010).

36 Washington J. McCormick, "Language by Legislation" (1923), w: James Crawford (ed.), Language Loyalties, op. cit., s. 41.

37 Tu i dalej: „Why Is Official English Necessary?”, strona internetowa organizacji U.S. English, http://www. us-english.org/view/10 (12.01.2010). 
w postępowaniach sądowych oraz w nauczaniu języków obcych i promocji turystyki (sic!). U.S. English zaznacza też, że wprowadzenie języka oficjalnego nie narzucałoby języka prywatnym firmom, nie ingerowałoby w język uroczystości religijnych czy rozmów prywatnych. W rzeczy samej, nałożenie przez rząd federalny ograniczeń językowych na firmy prywatne mogłoby stanowić naruszenie pierwszej i trzynastej poprawki do Konstytucji USA, gwarantujących, odpowiednio, wolność słowa i wypowiedzi oraz równe traktowanie. Na tej podstawie, przykładowo, decyzją Sądu Najwyższego Arizony w 1998 r. zostało unieważnione tamtejsze prawo Official English z 1986 r. ${ }^{38}$

Przeciwnicy wprowadzenia angielskiego jako języka oficjalnego nie zgadzają się z argumentami ruchu English-Only. Ich zdaniem pozycja angielskiego nie jest w żadnym wypadku zagrożona, gdyż nawet w grupach takich jak grupa latynoska, uchodząca za pielęgnującą język macierzysty, wyraźna jest tendencja do asymilacji językowej, a co za tym idzie, zmiany języka na angielski w kolejnych pokoleniach imigrantów. Hiszpański jako dominujący w pierwszym pokoleniu, w drugim i kolejnych ustępować powoli zaczyna miejsca angielskiemu, by ostatecznie w wielu wypadkach wyprzeć hiszpański całkowicie ${ }^{39}$. Dzieje się tak właśnie z powodu, który tak mocno podkreśla U.S. English - jedynie znajomość angielskiego daje imigrantom możliwość pełnego udziału w społeczeństwie amerykańskim, kształcenia się oraz awansu społecznego. Dwujęzyczność należy zatem raczej postrzegać jako zdecydowaną korzyść, również dla USA, a nie jako zagrożenie.

Organizacja U.S. English ma poparcie wielu prominentnych postaci. W składzie jej Advisory Board znajduje się obecny gubernator stanu Kalifornia Arnold Schwarzenegger ${ }^{40}$. Jak podaje Crawford, poparcia udzielili też m.in.: były prezydent USA Richard Nixon, senator Eugene McCarthy oraz osobistości ze świata literatury i filmu: Saul Bellow, Charleton Heston oraz Whoopi Goldberg, jak również inni, którzy w późniejszym okresie odcięli się od organizacji11. W ciągu kilku lat od swego powstania organizacja znacznie zwiększyła liczbę członków - z 300 osób w 1983 r. do 400 tys. w roku 1990. W 2000 r. miała zrzeszać 1,4 mln członków, zaś w 2009 r. - 1,8 mln osób z całego kraju². Ankiety przeprowadzone przez samą organizację pokazały, jak podaje Crawford, że jej członkami są w większości majętni, wykształceni mężczyźni powyżej 60. roku życia, konserwatyści o korzeniach z Europy Północnej ${ }^{43}$.

Krytycy i obserwatorzy dopatrują się jednak ukrytego programu (covert agenda) w dziatalności ruchu English Only. Miałby nim być, jak pisze James Crawford, „opór wobec rasowej i kulturowej różnorodności w Stanach Zjednoczonych"44. Mogłyby o tym świadczyć powiązania U.S. English (mimo zaprzeczeń ze strony samej organizacji) z grupami, których działania są jawnie antyimigranckie, np. FAIR ${ }^{45}$ (Federation for American Immi-

\section{- ・ • •}

38 Szerzej na ten temat oraz na temat innych spraw sądowych wnoszonych przeciwko regulacjom Official English, zob.: Carol L. Schmid, op. cit., s. 61-68.

39 Zob. np.: „Survey Brief - Bilingualism”, Pew Hispanic Center/Kaiser Family Foundation, Washington, D.C March 2004, http://pewhispanic.org/files/factsheets/12.pdf (18.04.2007).

40 Strona internetowa organizacji U.S. English: http://www.us-english.org/view/309 (12.01.2010).

41 James Crawford, At War with Diversity, op. cit., s. 5.

42 Carol L. Schmid, op. cit., s. 44. „About US English”, http://www.us-english.org/view/2 (12.01.2010).

43 James Crawford, At War with Diversity, op. cit., s. 24.

44 Ibid., s. 23

45 FAIR - organizacja powstała w 1979 r., działająca na rzecz ograniczenia imigracji (reformy polityki imigracyjnej, w tym wzmocnienia ochrony granic). Jak pisze James Crawford, przyjęła ona ponad 1 mln dolarów od Pioneer Fund - organizacji popierajacej ulepszanie rasy (race betterment) w drodze eugeniki, finansującej badania nad związkiem między rasą a inteligencją oraz popierającą restrykcyjną politykę imigracyjną. Pioneer Fund sfinansowała również książke opiewająca założyciela Ku-Klux-Klanu. James Crawford, At War with Diversity, op. cit., s. 23-24. Zob. też Heidi Beirich, „The Teflon Nativists. FAIR Marked by Ties to White Supremacy", Southern Poverty Law Center, Intelligence Report, Winter 2007, http://www.splcenter.org/intel/ intelreport/article.jsp?aid=846 (12.01.2010) 
gration Reform), którego twórca John Tanton był też współzałożycielem U.S. English. Związki z przeciwnikami imigracji oraz antyimigranckie uprzedzenia Tantona ujrzały światło dzienne wraz z wyciekiem memorandum z 1986 r., w którym Tanton niepochlebnie wyrażał się o Latynosach i przywoływał stereotypy rasowe. Napisał m.in.: "Czy obecna większość pokojowo odda swą władze polityczną grupie, która jest po prostu bardziej płodna? (...) Czy homo contraceptivus może mierzyć się z homo progenitiva, jeśli granice nie są kontrolowane?"46. Ujawnienie memorandum miało poważne konsekwencje dla Tantona i U.S. English. On sam odszedł z organizacji, z jej szeregów wycofało się też kilkoro ważnych członków, oburzonych treścią memorandum. Wpłynęło to również na przejściowy spadek poparcia dla organizacji i propozycji uregulowania statusu angielskiego ${ }^{47}$.

Poza U.S. English funkcjonuje kilka innych organizacji opowiadających się za uchwaleniem, by angielski był językiem oficjalnym: English First, American Ethnic Coalition oraz ProEnglish. English First stworzona została w 1986 r. przez Larry'ego Pratta, byłego reprezentanta Wirginii oraz prezydenta Gun Owners of America ${ }^{48}$. Jak podano na oficjalnej stronie internetowej organizacji, obecnie zrzesza ona około 150 tys. osób ${ }^{49}$. American Ethnic Coalition, założona w tym samym roku w Teksasie przez Lou Zaeske, ma na celu „zapobieżenie podziałom Ameryki wzdłuż linii językowych i etnicznych"50. Z kolei ProEnglish, w której Board of Directors zasiada obecnie współzałożyciel U.S. English, John Tanton, wywodzi swój początek z inicjatywy English Language Advocates z 1994 r. Występowała m.in. w obronie prawa Official English w Arizonie, które wkrótce potem zostało tam orzeczone jako niekonstytucyjne ${ }^{51}$.

JEZZYK ANGIELSKI JAKO OFICJALNY - WPROWADZONE REGULACJE ORAZ PROPOZYCJE

Od kiedy w 1981 r. Sayakawa zaproponował wspomnianą już poprawkę do Konstytucji, projekty Official English wielokrotnie powracały do Kongresu w różnych wersjach wielu autorów, proponujących odmienne rozwiązania prawne. Równocześnie z projektami ustanowienia angielskiego językiem oficjalnym k r a j u, w Kongresie rozpatrywano także pomysł ustanowienia angielskiego językiem $r$ z ą d u a m e r y k a ń s k i e g o. Pierwsza wersja ustawy Language of Government pojawiła się w czasie 102. kadencji Kongresu (1991-92)52. Propozycja taka została co prawda przegłosowana przez Izbę Reprezentantów w 1996 r., jednak ostatecznie nie głosowano nad nią w Senacie. Przyjęcie tej regulacji oznaczałoby, że angielski byłby wyłącznym językiem rządu, a więc w tym języku stanowione i egzekwowane byłyby prawa federalne.

\section{- $\cdots \cdot \cdot$}

46 Tekst memorandum dostępny na stronie internetowej Southern Poverty Law Center: „Memo to WITAN IV Attendees from John Tanton" (October 10, 1986), Southern Poverty Law Center, Intelligence Report, Summer 2002, http://www.splcenter.org/intel/intelreport/article.jsp?sid=125 (12.01.2010).

47 Zob. też: James Crawford, At War with Diversity, op. cit., s. 23, 32-34.

48 Jamie B. Draper, Martha Jimenez, „A Chronology of the Official English Movement”, 1996, http://www.usc. edu/dept/education/CMMR/PolicyPDF/OfficialEnglishDraperJimenez.pdf, s. 3 (12.01.2010).

49 „About English First”, http://englishfirst.org/englishfirst/ (12.01.2010).

50 Jamie B. Draper, Martha Jimenez, op. cit., s. 3.

51 Strona internetowa ProEnglish, http://www.proenglish.org/main/gen-info.htm (12.01.2010).

52 Tekst propozycji H. R. 123 (Emerson) dostępny na stronie http://www.languagepolicy.net/archives/hr123a. htm (15.01.2010). 
W 2009 r. angielski był oficjalnym językiem w 28 stanach USA ${ }^{53}$, spośród których 3 - Nebraska, Illinois oraz Wirginia - przyjęły go jeszcze przed uformowaniem się ruchu English Only, natomiast Hawaje od 1978 r. są stanem oficjalnie dwujęzycznym. W Nebrasce przyjęcie angielskiego za język oficjalny w 1920 r. miało związek z antyniemieckimi nastrojami, jakie wzbudziła I wojna światowa, czemu towarzyszyło ogólnonarodowe negatywne nastawienie względem imigrantów na fali kampanii amerykanizacji ${ }^{4}$. W Illinois statut wprowadzający zapis o języku angielskim z 1969 r. stanowił poprawkę do zapisu z 1923 r., który ustanowił „amerykański” językiem oficjalnym. Jak wyraził to sponsor poprawki z lat 60., regulacja z 1923 r. była powodowana "histerią anglofobiczną"55. Prawo Official English w Wirginii (1981 r. z poprawkami z 1986 i 1996 r.) przyjęto tuż przed powstaniem organizacji U.S. English i było ono zapowiedzią obaw, które już wkrótce miały dać o sobie znać. Prawo to nie miało mieć bynajmniej znaczenia symbolicznego. Jak pisze Raymond Tatalovich: „Oczywistą motywacją wprowadzenia tego statutu był sprzeciw wobec dwujęzycznej edukacji" 56 .

Obok wspomnianych 28 stanów organizacja U.S. English wymienia jeszcze Luizjanę (1812) i Massachusetts $(1975)^{57}$. James Crawford zauważa jednak, że żaden z nich nigdy oficjalnie nie przyjął prawa Official English ${ }^{58}$. W wypadku Luizjany chodzi o regulacje wprowadzone na terenie odmiennym kulturowo i językowo, zakupionym od Francji przez USA w 1803 r. - tym bardziej że pozycja francuskiego była tam bardzo silna. W 1974 r. ochronę francuskiemu zapewniła ponadto konstytucja stanowa, uznająca prawo do zachowania dziedzictwa kulturowego i językowego ${ }^{59}$

Co interesujące, jak zauważają Jewelle Taylor Gibbs i Teiahsha Bankhead, tam, gdzie decyzję o ustanowieniu angielskiego językiem oficjalnym podejmowali legislatorzy, zazwyczaj prawo to ma znaczenie bardziej symboliczne, gdyż nie istnieje tam realne zagrożenie dla języka angielskiego. Z kolei w stanach, w których o przyjęciu prawa zadecydowali wyborcy (np. Arizona, Kalifornia, Kolorado i Floryda), regulacje te są wyrazem rzeczywistej troski mieszkańców i ich woli utrzymania dominującej pozycji języka angielskiego ${ }^{60}$. Dlaczego jednak wyborcy poparli pomysł ustanowienia angielskiego językiem oficjalnym? Crawford sugeruje, że ma to związek z obecną imigracją do USA oraz zmianami, jakie powoduje ona w amerykańskich społecznościach czy miastach (np. zmiana składu etnicznego dzielnic, wzrost przestępczości etc.) ${ }^{61}$. A jednak, o czym wspomina Carol L. Schmid, poparcie społeczeństwa amerykańskiego w sondażach zależy w dużym stopniu od sposobu sformułowania pytania oraz od grupy objętej takim badaniem. Jak się

53 W kolejności alfabetycznej: Alabama (1990), Alaska (1998), Arizona (2006), Arkansas (1987), Floryda (1988), Georgia (1986 i 1996), Hawaje (stan oficjalnie dwujęzyczny od 1978 r.), Idaho (2007), Illinois (1969), Indiana (1984), lowa (2002), Kalifornia (1986), Kansas (2007), Kentucky (1984), Kolorado (1988), Missisipi (1987), Missouri (1998), Montana (1995), Nebraska (1920), New Hampshire (1995), Południowa Dakota (1995), Potudniowa Karolina (1987), Północna Dakota (1987), Północna Karolina (1987), Tennessee (1984), Utah (2000), Wirginia (1981, 1996), Wyoming (1996). Zapis o języku oficjalnym na Alasce (1998) został de facto unieważniony przez sąd okręgowy w $2002 \mathrm{r}$.

54 Szerzej na temat Official English w Nebrasce zob.: Raymond Tatalovich, Nativism reborn?: the official English language movement and the American states, The University Press of Kentucky, 1995, s. 33-62.

55 Washington J. McCormick, op. cit., s. 37. Szerzej na temat Official English w Illinois, zob.: Raymond Tatalovich, op. cit., s. 65-69.

56 Szerzej na temat Official English w Wirginii, zob.: Raymond Tatalovich, op. cit., s. 195-200.

57 "States with Offical English Laws”, strona internetowa organizacji U.S. English, http://www.usenglish.org/ view/13 (20.01.2010).

58 Szerzej zob.: James Crawford, „Canards”, http://www.languagepolicy.net/archives/canards.htm (20.01.2010).

59 Dennis Baron, The English-Only Question, op. cit., s. 87. Tekst konstytucji zob.: http://senate.legis.state. la.us/documents/Constitution/constitution.pdf (2.01.2010).

60 Jewelle Taylor Gibbs, Teiahsha Bankhead, Preserving Privilege. California Politics, Propositions, and People of Color, Praeger, Westport-London 2001, s. 131.

61 Szerzej zob.: James Crawford, At War with Diversity, op. cit., s. 24-27. 
okazuje, większym poparciem cieszy się ogólna idea uznania angielskiego jako oficjalnego, jeśli nie towarzyszy jej dodatkowa informacja na temat ewentualnych ograniczeń i konsekwencji z tego wynikających. Powiązane jest to bezpośrednio, jak się wydaje, z symbolicznym znaczeniem angielskiego dla Amerykanów jako niezbywalnego elementu tożsamości narodowej. Jeśli jednak w pytaniu pojawiają się szczegóły oraz dodatkowe wyjaśnienia na temat funkcjonowania prawa Official English (np. zakaz posługiwania się innymi językami niż angielski przez instytucje państwowe nawet tam, gdzie angielskim posługuje się bardzo mało osób), poparcie dla tej regulacji jest mniejsze. Stąd wyniki sondaży wahają się od $50 \%$ do nawet niemal $90 \%$ głosów za ustanowieniem angielskiego językiem oficjalnym ${ }^{62}$.

Niektóre stany wprowadzają także inne, poza Official English, regulacje w pewnym zakresie ograniczające użycie języków obcych. Pod tym względem wyróżnia się Kalifornia ${ }^{63}$. W 1983 r. w San Francisco przegłosowano zniesienie dwujęzycznych kart do głosowania (Proposition 0) ${ }^{64}$. Rok później cała Kalifornia przegłosowała podobną, sponsorowaną przez S.I. Hayakawę i innych liderów U.S. English, Proposition 38 („Voting Materials in English Only"). Kalifornia tym samym sprzeciwiła się federalnym zarządzeniom o kartach dwujęzycznych, jakie gwarantuje poprawka z 1975 r. do Voting Rights Act (1965), która w określonych wypadkach wymaga zapewnienia kart do głosowania w innych językach ${ }^{65}$. Jednak wynik głosowania zarówno nad Propositon 0, jak i Proposition 38 nie miał mocy wiążącej ze względu na to, że, jak zauważa Kathryn A. Woolard, legislacja federalna jest nadrzędna w stosunku do stanoweje6.

Zwolennikom angielskiego nie podoba się też, że w wielu stanach możliwe jest podejście do egzaminu na prawo jazdy w obcych językach. Wśród tych, które obecnie oferują najwięcej możliwości pod tym względem znajdują się: Kalifornia (32 języki), Massachusetts (25), Kentucky (23), Connecticut (21) oraz lowa (21) $)^{67}$. Jednak w ostatnich latach, jak podaje U.S. English, liczba stanów, które ograniczyły liczbę dostępnych języków była większa (8) niż tych, które ją zwiększyły (7). Wzrosła równocześnie liczba stanów, które dopuszczają egzaminy w y † ą c z n i e w języku angielskim. Obecnie jest ich 8: Maine, New Hampshire, Południowa Dakota, Wyoming, Arizona, Kansas, Utah oraz Hawaje ${ }^{68}$.

Decyzje o ograniczaniu użycia języków obcych zapadają również na jeszcze niższych szczeblach władzy - a mianowicie na poziomie hrabstwa czy nawet miast, a na przykład w 1980 r., zatem jeszcze przed powstaniem organizacji U.S. English, a nawet przed zaproponowaniem przez Hayakawę poprawki do Konstytucji, mieszkańcy hrabstwa Dade (Dade County) na Florydzie, gdzie skupia się znacząca grupa imigrantów z Kuby, przegłosowali bardzo restrykcyjną Antibilingual ordinance. Zakazała ona wydatkowania funduszy publicznych na inne języki niż angielski, zmieniając tym samym rezolucję przyjętą 7 lat wcześniej (1973), kiedy oficjalnie hrabstwo ogłoszono „dwujęzycznym i dwukulturowym”

62 Carol L. Schmid, op. cit., s. 76.

63 Tu i dalej za: Jamie B. Draper, Martha Jimenez, op. cit.

64 Szerzej na temat Proposition 0, zob. Kathryn A. Woolard, „Voting Rights, Liberal Voters and the Official English Movement: An Analysis of Campaign Rhethoric in San Francisco's Proposition '0'", w: Karen L. Adams, Daniel T. Brink (eds.), Perspectives on Official English: the campaign for English as the official language of the USA, Mouton de Gruyter, Berlin-New York 1990, s. 125-138.

65 Szerzej zob.: "About Language Minority Voting Rights", United States Department of Justice, Civil Rights Division, http://www.justice.gov/crt/voting/sec_203/activ_203.php (16.01.2010). Lista języków w poszczególnych stanach na stronie internetowej U.S. English: „Fact Sheets: Multilingual Ballots”, U.S. English, http://www.us-english.org/view/306 (16.01.2010).

66 Kathryn A. Woolard, op. cit., s. 125.

67 Zob.: "Fact Sheets: Languages Used for Driver's License Exams”, U.S. English, http://www.us-english.org/ view/305 (16.01.2010).

68 „U.S. English Study Highlights Multilingualism...", op. cit. 
(angielsko-hiszpańskim) ${ }^{69}$. Na mocy Antibilingual ordinance usunięto wszystkie hiszpańskojęzyczne oznaczenia i rozkłady jazdy, zakazano publikacji ulotek informacyjnych w tym języku, a nawet zniesiono ceremonie zawarcia związku małżeńskiego w języku hiszpańskim $^{70}$. Jak podaje James Crawford, w 1984 r. przyjęto jednak poprawkę, na mocy której fundusze hrabstwa mogły być wydawane na ochronę zdrowia publicznego, nagłe wypadki oraz w celu promocji turystyki ${ }^{71}$. Ostatecznie Antibilingual ordinance została uchylona w $1993 r^{72}$

Hrabstwo Dade nie jest jednak odosobnione w swych dążeniach do ograniczenia języków obcych. W niektórych miastach w okolicach Los Angeles (m.in. Monterrey Park czy Pomona) istniały regulacje ograniczające użycie napisów w innych językach na szyldach handlowych (business signs), czego powodem był duży napływ imigracji azjatyckiej w latach $80 .{ }^{73}$ U.S. English i inne organizacje donoszą też co pewien czas o kolejnych amerykańskich miastach rzekomo wprowadzających regulacje Official English ${ }^{74}$, jednak trudno o rzetelną i wiarygodną listę.

\section{KRYTYKA OFFICIAL ENGLISH}

Powracającym projektom Official English stale towarzyszy krytyka ze strony przeciwników tego pomysłu. Na przykład w 1987 r. w Kongresie pojawiła się propozycja poprawki do Konstytucji, która zamiast ograniczać, gwarantowałaby prawa kulturowe mieszkańcom (A Cultural Rights Amendment). Zaproponowana przez demokratów z Luizjany - senatora Johna Breaux oraz reprezentanta Jimmy'ego Hayesa - dawałaby „prawo do zachowania, rozwoju oraz propagowania korzeni historycznych, językowych i kulturowych"75. Kongres nie zajął się jednak tym projektem.

Do Kongresu trafiają też propozycje rezolucji English Plus. Stoi ona w całkowitej opozycji do Official English, podkreślając korzyści płynące z dwujęzycznej edukacji. Zdaniem zwolenników English Plus, zamiast zakazywać dwujęzycznej edukacji i narzucać język angielski, należałoby raczej zadbać o wysoki poziom tego języka, a równocześnie zachęcać do nauki języka macierzystego imigrantów. Dwujęzyczność może bowiem przynieść wiele korzyści nie tylko jednostkom, ale także poszczególnym stanom, a nawet całemu krajowi. W ten sposób Stany Zjednoczone mogłyby zyskać wielu dwujęzycznych ekspertów, co zwiększyłoby prestiż państwa na arenie międzynarodowej76. Pierwszym stanem, który zaaprobował niewiążącą rezolucję English Plus stał się w 1989 r. Nowy Meksyk ${ }^{77}$. Idąc jego śladem, to samo uczyniły Oregon i Waszyngton, a w 1992 r. - Rhode Island.

69 Wprowadzenie do „Dade County Antibilingual Ordinance”, w: James Crawford (ed.), Language Loyalties, op. cit., s. 131.

70 Jamie B. Draper, Martha Jimenez, op. cit.

71 Zob.: wprowadzenie do „Dade County Antibilingual Ordinance”, zob. James Crawford (ed.), Language Loyalties, op. cit., s. 131.

72 James Crawford, At War with Diversity, op. cit., s. 26

73 Szerzej zob. np.: „Asian American Business Groups v. City of Pomona”, w: James Crawford (ed.), Language Loyalties, op. cit., s. 284-287.

74 Zob. np.: "Nashville, Tenn. passes official English law”, ProEnglish, 7 February 2007, http://www.proenglish.org/newsreleases/070207.html (12.02.2007), „Two Towns Adopt English as the Official Language. Farmers Branch, Texas and Taneytown, Maryland add to growing list", U.S. English, Inc., 14 November 2006, http://www.us-english.org/inc/news/preleases/viewRelease.asp?ID=229 (12.02.2007).

75 Cyt. w: Jamie B. Draper, Martha Jimenez, op. cit.

76 Zob. szerzej: „Statement of Purpose” koalicji English Plus Information Clearinghouse (EPIC): „The English Plus Alternative", w: James Crawford (ed.), Language Loyalties, op. cit., s. 151-153.

77 „English Plus Declaration In New Mexico", dostępna na stronie New Mexico Public Education Department http://www.ped.state.nm.us/BilingualMulticultural/dl09/New\%20Mexico\%20--\%20English\%20Plus\% 20 Resolution.pdf (16.01.2010). 
Dążenia i działania mające na celu ograniczenie użycia innych języków wyrażają przekonania jedynie części polityków czy społeczeństwa. Rząd federalny natomiast stara się wychodzić naprzeciw potrzebom osób nieposługujących się biegle językiem angielskim. Świadczą o tym wprowadzane w ostatnich dekadach przepisy, jak choćby: Bilingual Education Act (1968), wspomniana już poprawka z 1975 r. do Voting Rights Act z 1965 r., gwarantująca dostępność kart do głosowania w innych językach, Court Interpreters Act (1978), zapewniający tłumaczy sądowych, czy statuty nakazujące posługiwanie się językami obcymi w federalnych centrach zdrowia dla imigrantów oraz zapewnienie ulotek informacyjnych w tych językach ${ }^{78}$. Ponadto, szereg instytucji federalnych, jak np. urząd podatkowy Internal Revenue Service (IRS), Departament Sprawiedliwości czy U.S. Census Bureau, udostępniają materiały informacyjne w innych językach, a nawet oferują formularze i kwestionariusze w obcych językach.

Jedną z ostatnich regulacji jest zarządzenie Executive Order 13166 („Improving Access to Services for Persons with Limited English Proficiency"), podpisane przez prezydenta Clintona w 2000 r. Ma ono ułatwić dostęp do programów federalnych osobom, które, „W związku ze swoim pochodzeniem narodowym mają ograniczoną znajomość angielskiego"79. Zarządzenie to jest, rzecz jasna, szeroko krytykowane przez U.S. English ${ }^{80}$.

Równocześnie Kongres zapewnia jednak dominującą i nadrzędną w stosunku do innych języków pozycję angielskiego. W 1993 r. zatwierdził on, na przykład, poprawkę do Immigration and Nationality Act, na mocy której ceremonie nadawania obywatelstwa amerykańskiego mogą odbywać się wyłącznie po angielsku ${ }^{81}$. Znajomość angielskiego jest także wymagana od osób starających się o obywatelstwo amerykańskie ${ }^{82}$. Pokazuje to bezsprzecznie, jak ważnym elementem amerykańskiej tożsamości jest język angielski.

\section{OFFICIAL SPANISH?}

W kontekście tak dużego poparcia dla projektu ustanowienia angielskiego językiem oficjalnym na uwage zasługuje niewielkie, 3,5-tysięczne przygraniczne miasto El Cenizo w Teksasie, które w 1999 r. nadało specjalny status językowi h i s z p a ń s k i e m u, a nie angielskiemu. Według spisu powszechnego z 2000 r. niemal 99\% mieszkańców tego miasta stanowili Hispanics/Latinos, ponad 42\% - osoby urodzone poza USA, aż 33,5\% - osoby niebędące obywatelami USA, a ponad 90\% mieszkańców posługiwało się w domu językiem hiszpańskim³ ${ }^{83}$ Specyfika miasta powodowała, że udział mieszkańców w życiu miasta był niewielki, co z kolei utrudniało jego rozwój34. Przegłosowane rozporządzenie o języku hiszpańskim jako języku "głównym” miasta (Predominant Language Ordinance) miało na celu włączenie do szerszej społeczności tych osób, których poziom

78 Zob. też: Jody Feder, "English as the Official Language of the United States: Legal Background and Analysis of Legislation in the $110^{\text {th }}$ Congress", CRS Report for Congress, January 25, 2007, s. 12-14, http://www.ilw. com/immigrationdaily/news/2007,0515-crs.pdf (16.01.2010).

79 ".... improve access to federally conducted and federally assisted programs and activities for persons who, as a result of national origin, are limited in their English proficiency (LEP)". Executive Order 13166, http:// www.us-english.org/view/23 (16.01.2010).

80 Pełny tekst Executive Order 13166 oraz jego krytyka, szerzej zob. http://www.us-english.org/view/23 (16.01.2010).

81 Jamie B. Draper, Martha Jimenez, op. cit., s. 5

82 Szerzej zob.: A Guide to Naturalization, U.S. Citizenship and Naturalization Services, http://www.uscis.gov/ files/article/M-476.pdf, s. 37 (16.01.2010).

83 „Profile of General Demographic Characteristics: 2000, Geographic area: El Cenizo city, Texas," U.S. Census Bureau, http://censtats.census.gov/data/TX/1604822905.pdf (16.01.2010).

84 Tu i dalej za: Kenya Hart, „Defending Against a 'Death by English'. English-Only, Spanish-Only, and a Gringa's Suggestions for Community Support of Language Rights", Berkeley La Raza Law Journal, Vol. 14: 177, 2003, s. 200-201. 
znajomości angielskiego nie był wystarczający. Jak pisze Kenya Hart, jest to przykład legislacji, która „skupia się na rzeczywistych potrzebach członków społeczności"85. Mimo że sam dokument nie wspomina o hiszpańskim jako o "języku urzędowym", a jedynie "głównym", wiele osób uważa jednak, że de facto wprowadza on prawo Spanish-Only6.

UWAGI KOŃCOWE

Wprowadzenie przepisów ograniczających użycie języków innych niż angielski, a zwłaszcza regulacji Official English, w poszczególnych stanach USA prowadziło do incydentów, które dotknęły nie tylko imigrantów, ale również amerykańskich obywateli posługujących się językami innymi niż angielski. Za Dennisem Baronem można tutaj przytoczyć kilka przykładów ${ }^{87}$. W Miami zawieszono w pracy kasjera supermarketu za porozumiewanie się ze swoimi współpracownikami po hiszpańsku. W Kolorado kierowca autobusu szkolnego zakazał korzystającym z niego dzieciom rozmów po hiszpańsku. W tym samym stanie zwolniono pracownika restauracji za przetłumaczenie menu klientowi z Ameryki Południowej. Inne przykłady language vigilantism, które miały miejsce po przyjęciu w 1996 r. przez Izbę Reprezentantów regulacji o języku angielskim jako języku rządu amerykańskiego, przytacza z kolei James Crawford. O ile być może nie dziwi już tak bardzo wywieszanie w barach informacji o obsługiwaniu klientów wyłącznie w języku angielskim, o tyle niepokoić może jednak to, że niektóre z tych przykładów pokazują nietolerancję funkcjonariuszy państwowych, a nawet pracowników wymiaru sprawiedliwości ${ }^{88}$. Na przykład w Amarillo (Teksas) sędzia orzekający w sprawie opieki nad dzieckiem oskarżył matkę o znęcanie się nad dzieckiem (child abuse), ponieważ mówiła do swej pięcioletniej córki po hiszpańsku. Policja w Yonkers (Nowy Jork) ukarała mandatem kubańskiego (Cuban-American) kierowcę ciężarówki, gdyż nie potrafił odpowiedzieć po angielsku na zadane mu pytania. W Norcross (Georgia) pastor hiszpańskojęzycznej kongregacji został ukarany grzywną za wywieszenie afiszy w tym języku. Z kolei w Huntsville (Alabama) odmówiono ulg podatkowych koreańskim właścicielom nieruchomości, którzy nie posługiwali się biegle językiem angielskim. Wszystkie te przykłady dają wyraz skrajnej nietolerancji oraz niechęci wobec mniejszości językowych.

Według danych U.S. Census Bureau z ostatniego spisu powszechnego, w 2000 r. niemal 18\% populacji USA posługiwało się $w$ domu innym językiem niż angielski, z czego większość mówiła po hiszpańsku9. Dane ze spisu z 2010 r. mogą wykazać jeszcze wyższy odsetek. Jednak nawet zakładając dalszy szybki wzrost liczebny grupy Hispanic/Latino, pozycja angielskiego nie wydaje się zagrożona. Badania potwierdzają bowiem, że imigranci również z tej grupy ulegają ostatecznie asymilacji językowej, a wierność językowi jest pozorna i wynika ze stałego napływu imigrantów z Ameryki Łacińskiej ${ }^{90}$. Wygląda za-

85 Ibid., s. 200.

86 Szerzej zob.: Ibid., s. 201-208.

87 Zob.: Dennis Baron, op. cit., s. 20-21.

88 Tu i dalej za: James Crawford, „Official English Legislation: Bad for Civil Rights, Bad for America's Interests, and Even Bad For English", Testimony before the U.S. House Subcommittee on Education Reform, 26 July 2006, s. 5, http://www.elladvocates.org/documents/englishonly/Crawford_Official_English_testimony.pdf (16.01.2010).

89 „Profile of Selected Social Characteristics: 2000, Geographic area: United States”, U.S. Census Bureau, http://censtats.census.gov/data/US/01000.pdf (16.01.2010).

90 Tendencję do zanikania jezzyka hiszpańskiego w kolejnych pokoleniach imigrantów potwierdza np. raport 2002 National Survey of Latinos. Summary of Findings, Pew Hispanic Center/Kaiser Family Foundation, Washington, D.C. December 2002, s. 16. 
tem na to, że walka o język jest de facto walką o ograniczenie imigracji do USA. Nadmierny napływ imigrantów z określonego regionu czy kraju, szczególnie jeśli przybysze różnili się pod względem kulturowym od Amerykanów, zazwyczaj prowadził bowiem z jednej strony do wzrostu nastrojów antyimigranckich i ksenofobicznych oraz prób ograniczenia ich napływu, z drugiej zaś - do prób zamerykanizowania nowych przybyszów. Carol L. Schmid zauważa, że ruch English Only jest przykładem nacjonalizmu kulturowego, skupiającego się na przedefiniowaniu tożsamości narodowej91. Tego rodzaju ruchy widoczne są w państwach osadniczych (settler states) oraz w krajach Europy Zachodniej, takich jak Niemcy, Francja, Wielka Brytania oraz Szwajcaria, które muszą mierzyć się z problemem dużego napływu imigrantów, w tym pracowników tymczasowych. Istotnie, tego rodzaju tendencje potwierdzają wydarzenia ostatnich lat w Europie Zachodniej, jak na przykład zakaz budowania minaretów w Szwajcarii, debata towarzysząca muzułmańskiej obecności we Francji, czy antypolskie nastroje w Wielkiej Brytanii. W każdym z tych przypadków w powszechnej opinii imigranci są postrzegani jako niepożądani i zagrażający kulturze oraz dobrobytowi mieszkańców danego kraju.

$\mathrm{Na}$ inny ważny aspekt zwrócił uwage znany amerykański socjolingwista Joshua A. Fishman ${ }^{92}$. Zwolennicy Official English/English Only uparcie koncentrują swą uwage na imigrantach oraz na pomocy językowej, jakiej ewentualnie oni wymagają. A tymczasem ważniejsze jest pytanie o to, dlaczego kolejne pokolenia imigrantów Hispanics/Latinos, posługujących się już także (a czasem wyłącznie) językiem angielskim, nadal pozostają w swoich barrios. Znajomość angielskiego nie wpływa bowiem na mobilność społeczną Hispanics, podobnie jak ma to miejsce w przypadku czarnych Amerykanów. Oznacza to, że największym problemem nie jest znajomość lub nieznajomość języka angielskiego, sam język nie jest bowiem jedynym gwarantem rozwoju i zmiany pozycji w społeczeństwie. Geneza English Only leży w głębszych problemach natury ekonomicznej, politycznej i kulturowej, a strach i obawy klasy średniej uzewnętrzniają się pod postacią ruchu Official English/English Only. Niechęć wobec imigrantów, którzy są doskonałymi kozłami ofiarnymi, to zatem rodzaj wentylu bezpieczeństwa. Jak napisał Fishman, amerykańska klasa średnia reaguje niechęcią wobec „obcokrajowców”, m.in. z powodu zmian społeczno-ekonomicznych w USA (spowolnienie gospodarki, dyskurs pluralizmu kulturowego, mniejsze szanse na awans społeczny kolejnych pokoleń etc.).

Od czasu, gdy Fishman sformułował swe opinie, minęło 20 lat. W tym czasie imigracja z Ameryki Łacińskiej, głównie z Meksyku, przybrała na sile. Badania pokazują jednak, że podobnie, jak miało to miejsce wcześniej, kolejne pokolenia imigrantów przechodzą na angielski. Nie ma też oznak tendencji separatystycznych, nie powstają etniczne partie polityczne. Za atakami terrorystycznymi w Stanach Zjednoczonych nie stały zaś grupy etniczne (kulturowe), ale religijni fundamentaliści z globalnej organizacji. A mimo upływu czasu grupa latynoska jako całość nadal plasuje się poniżej średniej krajowej zarówno pod względem poziomu wykształcenia, jak i dochodu czy innych wskaźników ${ }^{93}$, co potwierdza tezę, że znajomość języka nie wpływa (znacząco) na mobilność społeczną.

Jak stwierdził James Crawford, dyrektor Institute for Language and Education Policy, w wystąpieniu przed Podkomisją Kongresu ds. Reformy Edukacji, ustanowienie angiel-

91 Carol L. Schmid, op. cit., s. 9-10.

92 Joshua A. Fishman, „'English Only': Its Ghosts, Myths and Dangers”, International Journal of the Sociology of Language 74 (1988), w: James Crawford (ed.), Language Loyalties, op. cit., s. 165-170.

93 Zob. np.: Roberto R. Ramirez, „We the People: Hispanics in the United States”, Census 2000 Special Reports, U.S. Census Bureau, Washington, D.C. December 2004, http://www.census.gov/prod/2004pubs/ censr-18.pdf (16.01.2010). 
skiego oficjalnym językiem kraju nie jest dobrym pomysłem. Po pierwsze, jego zdaniem, jest to niepotrzebne, ponieważ pozycja angielskiego nie jest zagrożona, a imigranci szybko go sobie przyswajają. Po drugie, ograniczyłoby to rządowi możliwość komunikacji z milionami osób w USA, w tym z obywatelami amerykańskim nieposługującymi się biegle angielskim, co stanowiłoby pogwatcenie ich praw. Po trzecie, prawo Official English nie oferuje żadnej pomocy osobom uczącym się języka angielskiego, a uniemożliwiłoby tworzenie programów mających im to ułatwić. Po czwarte, prawo to pobudzi nienawiść do grup mniejszościowych, w szczególności zaś względem Azjatów i Latynosów. Po piąte, Official English jest sprzeczne z wartościami amerykańskimi, ponieważ, co potwierdzity wyroki sądów, tamie m.in. prawo do wolności wypowiedzi. I wreszcie, regulacja taka sama w sobie jest bezcelowa - w czasach globalizacji wielojęzyczność jest bowiem, jego zdaniem, zdecydowanym atutem, a nie wadą ${ }^{94}$.

Zwolennicy Official English nie ustają jednak w swoich działaniach. W Kongresie znajduje się obecnie (111. kadencja Kongresu) kilka projektów - 7 w Izbie Reprezentantów oraz 2 w Senacie ${ }^{95}$. Wśród nich są, rzecz jasna, propozycje ustanowienia angielskiego językiem oficjalnym rządu USA, czy językiem oficjalnym kraju oraz regulujące wymogi dotyczące naturalizacji. Inne projekty dotyczą kart do głosowania lub unieważnienia rozporządzenia wykonawczego 13166. Wkrótce też o statusie angielskiego zadecydują mieszkańcy Oklahomy. Głosowanie jest tam przewidziane, jak podaje U.S. English, na 2 listopada 2010 r. ${ }^{96}$ Towarzysząca debata oraz kampania na rzecz wprowadzenia tej regulacji będzie kolejną okazją do wsłuchania się dokładniej zarówno w argumenty działaczy ruchu i ich przeciwników, jak i przyjrzenia się społeczeństwu amerykańskiemu.

\section{ONE NATION - ONE LANGUAGE? ENGLISH-ONLY MOVEMENT IN THE UNITED STATES}

\section{Summary}

Speaking English is perceived as essential to American identity. English language does not, however, have an official status in the United States. As a consequence of the change in the racial and ethnic composition of the US population, in particular the growth of the Hispanic/Latino minority, since the 1980s the country has witnessed the birth and growth of the English-Only Movement. The aim of the movement is to give English an official status. Even though no federal regulations have yet been passed, Official English measures have been adopted by many American states.

This article presents the English-Only Movement within the context of earlier attempts to restrict the use of foreign languages in the US. It also briefly discusses some of the federal, state and local regulations.

Keywords: English-Only Movement, Official English, United States, American identity

94 James Crawford, „Official English Legislation: Bad for Civil Rights...”, op. cit., s. 1-2 (16.01.2010).

95 Lista oraz treść projektów znajduje się na stronie internetowej organizacji U.S. English, http://www.usenglish.org/view/310 (16.01.2010).

96 Strona internetowa U.S. English, http://www.usenglish.org/view/13 (16.01.2010). 